\title{
PENGARUH PEMBELAJARAN IPS MODEL DISCOVERY LEARNING TERHADAP KEMAMPUAN BERPIKIR KREATIF SISWA PADA MATERI DINAMIKA INTERAKSI MANUSIA DENGAN LINGKUNGAN KELAS VII SEMESER GENAP SMP MUHAMMADIYAH 12 GRESIK
}

\author{
Hari Widianto* \\ Pengajar di SMP Muhammadiyah 12 Gresik \\ Email: hari_widianto@yahoo.com
}

\begin{abstract}
Abstrak
Penelitian ini bertujuan mengkaji pengaruh penggunaan model Discovery Learning terhadap kemampuan berpikir kreatif siswa pada pembelajaran IPS tentang dinamika interaksi manusia dengan lingkunga. Subyek penelitian yang digunakan alam penelitian ini adalah siswa kelas VII SMP Muhammadiyah 12 Gresik. Meliputi 3 kelas yang digunakan dalam penelitian ini diantaranya kelas VII-G sebagai kelas uji coba, VII-E sebagai kelompok eksperimen dan VII-F sebagai kelompok kontrol. Kelas uji coba dimaksudkan sebagai kelas yang digunakan untuk menguji instrumen yang akan digunakan untuk mengambil data kemampuan berpikir kreatif siswa.

Penelitian dengan pendekatan kuantitatif ini, ditinjau dari sudut perolehan nilai tes kemampuan berpikir kreatif peserta didik. Indikator kemampuan berpikir kreatif terdiri dari fluent thinking, flexible thinking, original thinking, dan elaborate thinking yang skor atau nilainya dijumlahkan dan dianalisis menggunakan independent uji t-2 sampel independent. Pada uji validitas diperoleh $r$-hitung $\geq r$ kritis $(0,334)$, yaitu item $1=0,57$ dan item $2=0,56$ maka instrumen dikatakan valid dan dapat digunakan. Pada uji reliabel $r$-hitung $\geq \mathrm{r}$ kritis $(0,60)$, yaitu nilai $\alpha$ sebesar 0,80 yang berarti lebih besar dari 0,60 , dengan demikian keseluruhan item instrumen adalah reliabel. Hasil pengujian hipotesis dapat diketahui dari data yang telah dianalisis dengan t hitung 7,633>t-tabel 2,00 $(\alpha=0,05)$. Dapat disimpulkan bahwa probabilitas kesalah dalam penelitian ini masih dibawah 0,05. Pengujian hipotesis dapat diputuskan, bahwa dengan tingginya harga t hitung sebesar 7,633 memiliki taraf signifikansi 0,000 yang ternyata kedudukannya masih jauh berada dibawah nilai $\alpha=0,05$.

Dengan demikian penelitian ini berhasil menolak $H O$ pada taraf signifikansi $5 \%$. Selanjutnya dapat disimpulkan bahwa $H 1$ terbukti benar. Mean pretes pada kelompok eksperimen adalah 69 dan postes kelompok eksperimen adalah 83,1. Sedangkan mean pretes kelompok kontrol adalah 68 dan postes kontrol adalah 75,5. Hal ini membutikan bahwa telah terjadi peningkatan nilai pada kelompok eksperimen yang telah diberikan perlakuan dengan model pembelajaran Discovery Learning. Dengan demikian dapat disimpulkan kemampuan berpikir kreatif peserta didik pada kelompok eksperimen lebih tinggi daripada kelompok kontrol. Model pembelajaran Discovery Learning berpengaruh positif terhadap kemampuan berpikir kreatif peserta didik.
\end{abstract}

Kata Kunci: Model Pembelajaran Discovery Learning ;Kemampuan Berpikir Kreatif. 


\begin{abstract}
This is study aims to asses the effect of the use of Discovery Learning model for creative thinking abilities in teaching social studies on dynamics of human interaction with the environment. Subject of this research is a class VII SMP Muhammadiyah 12 Gresik. Overing three classes used in this study, include VII $G$ as a class test, VII E as the experimental group, and VII $F$ as a control group. Lass tests are intended to test the instruments which will be used to retrieve data students' crative thinking abilities.

This is a quantitative research approach based on the test scores of creative thinking abilities. The indicators of creative thinking abilities consist of fluent thinking, flexible thinking, original thinking, and elaborate thinking in which the scores or values are totaled and analyzed using t-test two independent samples. On the validity test, it is obtained that the $\mathrm{r}$ counting $\geq \mathrm{r}$ critical $(0.334)$, namely item $1=0.57$ and item $2=0.56$ which are considered as valid and it can be used. In the test of reliability, the $r$ counting $>r$ critical (0.60), namely $\alpha$ value 0,80 means greater than 0.60 . Thus the entire items instrument is reliable. The result of hypothesis testing can be seen from the data that has been analyzed by t- counting 7,633>t-table $2,00(\alpha=0,05)$. It can be concluded that the probability of error in this study still bellow 0.05 . Hypothesis testing can be decided that with the high price of 7,633 t-test has significance level of 0.000 turning out be the position which is stil far below the value of $\alpha=0,05$.

This study threfore managed to reject $\mathrm{H} 0$ at significance level of 5\%. Furthermore, it can be concluded that the $\mathrm{H} 1$ was proved right. Mean in the pretest of the experimental group is 69 and Mean in the posttest of the experimental group is 83.1. While the mean pretest of the control group is 68 and the mean the posttest of the control group is 75.5. This is an evidence that the increasing scores of the experimental class happens after this class has been given the treatment with Discovery Learning model. Thus, we can conclude that the creative thinking abilities of students in the experimental group is higher than the control group. Indeed, Discovery Learning model has the positive effect on students' ability to thing creatively.
\end{abstract}

Keywords: Model Discovery Learning; Creative Thinking Ability.

\title{
PENDAHULUAN
}

Banyak peserta didik menganggap bahwa belajar IPS adalah suatu aktivitas yang dirasa sangat monoton dan tidak mengembangkan daya kreatifitas mereka. Kesulitan belajar Ilmu Pengetahuan Sosial bisa bersumber dari dalam diri peserta didik juga dari luar diri mereka, misalnya suasana kelas yang tidak kondusif dan tidak menyenangkan, dan juga faktor guru.
Untuk mengatasi masalah pembelajaran seperti itu, maka diperlukan inovasi metode pembelajaran Ilmu Pengetahuan Sosial. Dalam kegiatan pembelajaran, guru hendaknya memilih dan menggunakan strategi yang melibatkan siswa aktif belajar, baik secara mental, fisik maupun sosial. Pembelajaran dengan pendekatan scientific pada kurikulum 2013, akan melatih peserta 
didik untuk terbiasa memecahkan masalah-masalah sosial pada kehidupan sehari-hari disekitar lingkungan peserta didik dengan berpikir kritis, jernih dan ilmiah.

$$
\text { Pembelajaran IPS dengan }
$$
menerapkan model discovery learning bertujuan meningkatkan hasil belajar peserta didik dengan mendorong peningkatan kemampuan berpikir kreatif. Pemilihan model belajar ini diutamakan guna menimbulkan semangat motivasi belajar, merangsang peserta didik aktif berkontribusi dalam proses belajar mengajar di kelas, dan merangsang peserta didik berpikir kreatif diharapkan dapat meningkatkan kualitas proses pembelajaran IPS.

Kemampuan berpikir kreatif merupakan salah satu faktor penting dari tujuan pembelajaran karena memberi pengetahuan sematamata kepada siswa tidak akan banyak menolongnya dalam kehidupan seharihari, sehingga dalam pembelajaran sebaiknya dapat mengembangkan sikap dan kemampuan peserta siswa yang dapat membantu untuk menghadapi persoalan-persoalan di masa mendatang secara kreatif.

Ilmu Pengetahuan Sosial membahas hubungan antara manusia dengan lingkungannya. Lingkungan masyarakat dimana peserta didik tumbuh dan berkembang sebagai bagian dari masyarakat, tentunya dihadapkan pada berbagai permasalahan yang ada dan terjadi di lingkungan sekitarnya. Pendidikan IPS berusaha membantu peserta didik dalam memecahkan permasalahan yang dihadapi sehingga akan menjadikannya semakin mengerti dan memahami lingkungan sosial masyarakatnya. (Kosasih, 1994).

Menurut Martoella, 1987 (Solihatin dan Raharjo, 2008:14) mengatakan bahwa pembelajaran Pendidikan IPS lebih menekankan pada aspek "pendidikan" dari pada "transfer konsep", karena dalam pembelajaran pendidikan IPS peserta didik diharapkan memperoleh pemahaman terhadap sejumlah konsep dan mengembangkan serta melatih sikap, nilai, moral, dan keterampilannya berdasarkan konsep yang telah dimilikinya. Dengan mengaplikasikan model discovery learning secara berulang-ulang dapat meningkatkan kemampuan penemuan diri individu yang bersangkutan. Penggunaan model discovery learning, ingin merubah kondisi belajar yang pasif menjadi aktif dan kreatif. Mengubah pembelajaran yang teacher oriented ke student oriented. 


\section{A. Model Pembelajaran Discovery Learning}

Model pembelajaran discovery learning melatih siswa berpikir kreatif yaitu berpikir secara konsisten dan terus menerus menghasilkan sesuatu yang kreatif/orisinil sesuai dengan keperluan. Penelitian Brookfield menunjukkan bahwa orang yang kreatif biasanya (1) sering menolak teknik yang standar dalam menyelesaikan masalah, (2) mempunyai ketertarikan yang luas dalam masalah yang berkaitan maupun tidak berkaitan dengan dirinya, (3) mampu memandang suatu masalah dari berbagai perspektif, (4) cenderung menatap dunia secara relatif dan kontekstual, bukannya secara universal atau absolut, (5) biasanya melakukan pendekatan trial and error dalam menyelesaikan permasalahan yang memberikan alternatif, berorientasi ke depan dan bersikap optimis dalam menghadapi perubahan demi suatu kemajuan.

Model pembelajaran discovery learning adalah salah satu model pembelajaran dalam kurikulun 2013 dengan pendekatan saintifik. Kemendikbud (2013) memberikan konsepsi bahwa pendekatan saintifik dalam pembelajarannya didalamnya mencakup komponen : mengamati, mencoba, mengolah, menyajikan, menyimpulkan dan mencipta. Agar dapat disebut ilmiah, metode pencarian atau discovery harus berbasis pada bukti-bukti dari obyek yang dapat diobservasi, empiris dan terukur. Karena itu pendekatan ilmiah umumnya memuat rangkaian kegiatan koleksi data melalui observasi dan eksperimen, kemudian memformulasikan dan menguji hipotesis. Melalui model pembelajaran discovery learning akan melatih siswa berpikir kreatif sehingga dengan berpikir kreatif mampu meningkatkan prestasi belajar siswa.

Materi Dinamika Interaksi Manusia Dengan Lingkungan merupakan sub tema yang memiliki kompleksitas yang tinggi dan keterkaitan yang sangat erat dengan kehidupan sehari-hari peserta didik. Peserta didik diharapkan dapat memahami aspek Memahami pengertian dinamika interaksi manusia dengan lingkungan alam, sosial, budaya, dan ekonomi serta mengobservasi dan menyajikan bentuk-bentuk dinamika interaksi manusia dengan lingkungan alam, sosial, budaya, dan ekonomi di lingkungan masyarakat sekitar. Oleh karena itu untuk dapat memahaminya maka sangat diperlukan metode pembelajaran yang dapat menumbuhkan rasa senang peserta didik untuk dapat menyelidiki, mengorganisir dan 
menemukan konsep yang belum pernah diketahui.

\section{B. Berpikir Kreatif}

Beberapa permasalahan yang dihadapi peserta didik dalam pembelajaran IPS yang tentunya terkait dengan dengan persoalan lingkungan dan sosial adalah kesulitan untuk menemukan masalah baru dalam suatu peristiwaperistiwa sosial yang dipaparkan oleh guru melalui sebuah gambar atau film, pasif dan cenderung takut dalam berkomentar pada suatu kegiatan diskusi untuk menemukan masalah baru dan pemecahannya, kurang menarik dalam memaparkan penemuan masalah baru dan pemecahan masalahnya, dikarenakan enggan untuk menggunakan daya imajinasi mereka dan peserta didik dalam memaparkan penemuan masalah baru dan pemecahan masalah menganggap sebagai sesuatu permasalahan biasa atau sebagai sesugatu yang kurang menarik dan bahkan tidak menarik perhatian mereka untuk didiskusikan lebih serius.

Penerapan pembelajaran IPS dengan model discovery learning dengan tujuan meningkatkan hasil belajar peserta didik dengan mendorong peningkatan kemampuan berpikir kreatif. Pemilihan model belajar ini diutamakan guna menimbulkan semangat motivasi belajar, merangsang peserta didik aktif berkontribusi dalam proses belajar mengajar di kelas, dan merangsang peserta didik berpikir kreatif diharapkan dapat meningkatkan kualitas proses pembelajaran IPS.

\section{METODE PENELITIAN}

Penelitian yang digunakan dalam penelitian ini adalasih dengan menggunakan metode eksperimen dengan menggunakan pre-test pot-test control group design. Desain eksperimental dalam penelitian ini dilakukan terhadap dua kelompok siswa yang diberi perlakuan berbeda dengan materi pembelajaran yang sama. Kelompok eksperimen menggunakan model pembelajaran Discovery Learning sementara kelompok kontrol menggunakan metode konvensional.

Prosedur penelitian yang dilaksanakan pada proses pembelajaran terdiri dari persiapan, pelaksanaan dan tahap akhir. Pada tahap persiapan dipersiapkan segala sesuatu yang dibutuhkan untuk penelitian. Pada tahap pelaksanaan penelitian, dilakukan pembelajaran pada kelas kontrol dan kelas eksperimen. Pada kelas eksperimen diberikan perlakuan berupa pembelajaran matematika dengan model pembelajaran berbasis masalah, 
sedangkan pada kelas kontrol pembelajaran tanpa perlakuan atau konvensional. Pada tahap akhir kegiatan yang dilaksanakan adalah mengumpulkan data hasil penelitian dan mengolah data tersebut sehingga diperoleh kesimpulan.

Pengumpulan data dilakukan melalui pertama, validasi perangkat. Kedua, observasi. Ketiga, test. Teknik analisis data yang digunakan adalah uji beda rata-rata. Uji beda dalam penelitian ini adalah menggunakan Independent sample t-test yang bertujuan untuk membandingkan rata-rata skor hasil test dari dua grup yang yang tidak berhubungan satu dengan yang lain, apakah kedua grup tersebut mempunyai rata-rata yang sama atau tidak secara signifikan.

Instrumen yang digunakan dalam penelitian ini adalah lembar soal tes. Lembar soal tes untuk memperoleh data kemampuan berpikir kreatif siswa. Komponen kemampuan berpikir kreatif siswa diperoleh dari melihat kemampuan siswa dalam memecahkan masalah. Komponen yang dinilai antara lain kemampuan kefasihan, kemampuan keluwesan, kemampuan keaslian dan kemampuan penguraian.

Pelaksanaan penelitian ini dilakukan di SMP Muhammadiyah 12 Gresik di jalan Jawa 60 GKB Gresik. Waktu penelitian pada semester genap tahun pelajaran 2014-2015 yang direncanakan pada bulan April - Mei 2015. Subyek penelitian adalah peserta didik kelas VII (tujuh) tahun pelajaran 2014-2015 semester genap di SMP Muhammadiyah 12 Gresik. Pemilihan sampel dalam penelitian ini dilakukan dengan pemilihan kelompok yang dilakukan secara acak terhadap kelaskelas yang ada. Pemilihan kelas sebagai uji coba perangkat untuk mengetahui valid atau tidak valid soal yang digunakan untuk penelitian. Uji coba perangkat dilaksanakan pada kelas VII G dengan jumlah peserta didik 4 orang sebagai kelas uji coba, sampel penelitian diambil kelas VII E dengan jumlah peserta didik 30 orang sebagai kelas eksperimen dan kelas VII $\mathrm{F}$ dengan jumlah peserta didik 30 orang sebagai kelas kontrol.

\section{HASIL DAN PEMBAHASAN}

Berdasarkan penelitian yang telah dilakukan, diperoleh data kemampuan berpikir kreatif siswa. Data yang diperoleh antara lain data hasil pretest dan posttest siswa, dari hasil penilaian pre-test dan post-test (tes hasil belajar kreatif) pada kelas kontrol (Kls.VII F) maupun kelas eksperimen 
(kls. VII E). Pada kompetensi ini akan ditunjukkan hasil pre-test sebelum mendapatkan perlakuan model Discovery Learning dengan pendekatan saintifik dan post-test setelah mendapat perlakuan model Discovery Learning dengan pendekatan saintifik.

Berdasarkan penilaian hasil pretest dan post-test kemampuan berpikir kreatif kelas VII-E (kelas ekperimen) diperoleh keterangan bahwa hasil penilaian pre-test (sebelum pelaksanaan pembelajaran) dikategorikan rendah yaitu dengan nilai rata-rata mencapai 55,0 maka masih termasuk kategori cukup sedangkan setelah pelaksanaan pembelajaran, hasil nilai post-test dengan nilai rata-rata mencapai 83,8 dikategorikan sangat kreatif. Sedangkan hasil penilaian pre-test dan post-test kelas VII - F (kelas kontrol) yang tidak mendapatkan perlakuan discovery learning, berdasarkan penialian hasil pre-test dan post-test kemampuan berpikir kreatif kelas VII-F diperoleh data bahwa hasil penilaian pre-test (sebelum pelaksanaan pembelajaran) nilai rata-rata mencapai skor 49 maka masih termasuk kategori cukup sedangkan setelah pelaksanaan pembelajaran, hasil nilai post-test dengan nilai rata-rata mencapai 75 dikategorikan kreatif.

\section{Analisis Hasil Pre-test Kemampuan}

\section{Berpikir Kreatif siswa}

Berdasarkan pengujian hasil output dengan SPSS.16 Kolmogorov Smirnov test pada soal pre-test kemampuan berpikir kreatif diperoleh nilai Asymp Sig. Ialah 0,200 > 0,05 untuk kelas eksperimen (VII-E) dan untuk kelas kontrol (VII-F) ialah 0,200 >0,05. Hasil output homogenitas dengan metode Levene's Test menunjukkan bahwa nilai pada baris based on mean, yaitu 3,230 dengan (sig) sebesar 0,077>0,05. Berdasarkan uji normalitas dan uji homogenitas data pretest, diketahui bahwa kedua sampel berdistribusi normal dan varian dari kedua sampel bersifat homogen. Uji prasyarat pada pre-test menunjukkan bahwa analisis data dapat dilakukan dengan uji independent t-test. Uji independent t-test yang dilakukan dengan berbantuan SPSS.

\section{Analisis Hasil Post-test Kemampuan Berpikir Kreatif siswa}

Sedangkan hasil output dengan SPSS.16 Kolmogorov Smirnov test pada soal post-test diperoleh nilai Asymp Sig. Ialah $0,200>0,05$ untuk kelas eksperimen (VII-E) dan untuk kelas kontrol (VII-F) ialah 0,128 >0,05. Hasil output homogenitas dengan metode Levene's Test menunjukkan bahwa nilai pada baris based on mean, yaitu 2,210 
dengan (sig) sebesar 0,143 >0,05 Hasil ini menunjukkan bahwa data post-test berdistribusi normal dan homogen. Berdasarkan uji normalitas dan uji homogenitas data post-test, diketahui bahwa kedua sampel berdistribusi normal dan varian dari kedua sampel bersifat homogen. Uji prasyarat pada post-test menunjukkan bahwa analisis data dapat dilakukan dengan uji independent t-test. Uji independent t-test yang dilakukan dengan berbantuan SPSS.

Berdasarkan hasil analisis program komputer SPSS 0.16 for windows terhadap nilai siswa kedua kelompok dapat dilihat dari perbedaan rata-rata (difference mean) yaitu 9.647 artinya apabila difference mean nya bernilai positif maka kelas eksperimen (kelompok 1) memiliki mean lebih tinggi daripada kelas kontrol. Output SPSS memberikan $p$ value untuk uji dua sisi Sig (2 tailed) yaitu $0.000<0,05$ maka adanya perbedaan bermakna atau signifikan. Berdasarkan hasil output juga dapat dilihat bahwa $\mathrm{t}$ hitung lebih besar dari $\mathrm{t}$ tabel yaitu $8.369>1.697$. Berdasarkan hasil tersebut, maka nilai pre-test dan post-test memperoleh hasil yang tidak sama.

\section{Pembahasan}

Berdasarkan hasil analisis data didapatkan bahwa tidak terdapat pengaruh metode discovery learning terhadap kemampuan berpikir kreatif siswa. Hasil ini diperoleh karena beberapa langkah pembelajaran yang digunakan kelas eksperimen bagian dari scientific. Scientific merupakan landasan yang digunakan dalam menyusun kurikulum 2013. Kurikulum 2013 digunakan sebagai landasan pembelajaran kelas kontrol. Berdasarkan hasil tersebut, maka nilai pretest dan posttest memperoleh hasil yang tidak sama yaitu adanya perbedaan bermakna atau signifikan. Hal ini menunjukkan bahwa adanya pengaruh model pembelajaran Discovery Learning terhadap kemampuan berpikir siswa pada materi Dinamika Interaksi Manusia dengan Lingkungan. Hal ini sesuai dengan teori Brookfield, Marzano, Haris,

Penelitian Brookfield (1987) menunjukkan bahwa orang yang kreatif biasanya (1) sering menolak teknik yang standar dalam menyelesaikan masalah, (2) mempunyai ketertarikan yang luas dalam masalah yang berkaitan maupun tidak berkaitan dengan dirinya, (3) mampu memandang suatu masalah dari berbagai perspektif, (4) cenderung menatap dunia secara relatif dan kontekstual, bukannya secara universal atau absolut, (5) biasanya melakukan pendekatan trial and error dalam menyelesaikan permasalahan yang memberikan alternatif, berorientasi ke 
depan dan bersikap optimis dalam menghadapi perubahan demi suatu kemajuan.

Marzano (1988) mengatakan bahwa untuk menjadi kreatif seseorang harus: (1) bekerja di ujung kompetensi bukan ditengahnya, (2) tinjau ulang ide, (3) melakukan sesuatu karena dorongan internal dan bukan karena dorongan eksternal, (4) pola pikir divergen/ menyebar, (5) pola pikir lateral/imajinatif.

Haris (1995) dalam artikelnya tentang pengantar berpikir kreatif menyatakan bahwa indikator orang berpikir kreatif itu meliputi: (1) Ingin tahu, (2) mencari masalah, (3) menikmati tantangan, (4) optimis, (5) mampu membedakan penilaian, (6) nyaman dengan imajinasi, (7) melihat masalah sebagai peluang, (8) melihat masalah sebagai hal yang menarik, (8) masalah dapat diterima secara emosional, (9) menantang anggapan/ praduga, dan (10) tidak mudah menyerah, berusaha keras.

\section{PENUTUP}

$$
\begin{aligned}
& \text { Berdasarkan penilaian hasil } \\
& \text { belajar pre-test dan post test } \\
& \text { kemamampuan berpikir kreatif siswa pada } \\
& \text { kelompok eksperimen yang diajarkan } \\
& \text { dengan menggunakan pembelaran } \\
& \text { discovery learning lebih tinggi secara } \\
& \text { signifikan dibanding kelompok kontrol }
\end{aligned}
$$

dengan menggunakan pembelajaran langsung. langsung.

Hasil belajar siswa pada kelompok kelas eksprimen dan kelompok kelas kontrol menunjukkan adanya

perbedaan skor pre test dan post test yang signifikan, sehingga pembelajaran IPS dengan menggunakan model discovery learning lebih efektif dalam meningkatkan hasil belajar siswa. Hasil belajar ada kompetensi pengetahuan menunjukkan adanya perbedaan antara kelas eksperimen dan kelas kontrol. Pada kelas eksperimen terjadi peningkatan yang signifikan yaitu dari pretest 58,9 menjadi rata-rata posttest 82,0 Sedangkan pada kelas kontrol tidak terjadi peningkatan nilai yang signifikan yaitu dari rata-rata nilai pretest 60,7 menjadi rata-rata nilai posttest 73,6 .

Berdasarkan kesimpulan, maka peneliti menyarankan supaya guru IPS menggunakan model pembelajaran discovery learning yang dihasilkan dalam penelitian ini sebagai alternatif dalam memperkaya variasi model pembelajaran dan memperkaya kualitas pembelajaran di sekolah. 


\section{DAFTAR PUSTAKA}

Arends, R. I. 2008. Learning to teach: Belajar untuk Mengajar Buku I. Yogyakarta. Pustaka Belajar.

Aziz, Buhadi. 2014. Tesis. Penggunaan Model Pembelajaran Pengajuan Soal (Problem Posing) Untuk Meningkatkan Kemampuan Berpikir Kreatif Siswa Pada

Mata Pelajaran IPS di $\begin{array}{llll}\text { SMP } & \mathrm{N} & 1\end{array}$ Lamongan

Brookfield, 1987. Developing Critical. Jakarta: Bumi Aksara.

Bruner, J. 1969. The Act of Discovery. Cambridge. Harvard University Press.

Cahyo, Agus N. 2013. Panduan Aplikasi Teori-teori Belajar Mengajar (Teraktual dan Terpopuler). Yogyakarta: Diva Press

Dahar, R. W. 1989. Teori-teori belajar. Jakarta: Erlangga.

Dahlan,M.D. (1990). Model -Model Mengajar . Bandung : CV. Diponegoro

Depdiknas. Sistem Pendidikan Nasional. Pasal 3. Jakarta: Depdiknas.Dimyati dan Mudjiono. 1994. Belajar dan Pembelajaran. Jakarta: Direktorat Jendral Pendidikan Tinggi Departemen Pendidikan dan kebudayaan

Direktorat Tenaga Pendidik Dirjen PMPTK Depdiknas. 2008. Strategi Pembelajaran Pendidikan Kewarganegaraan dan Ilmu Pengathuan Sosial. Jakarta.

Dalam http://akhmadsudrajat.wordpress. com. Diunduh 15 maret 2015 pukul $14.00 \mathrm{wib}$

Dirjen PMPTK Depdiknas: 2008 dalam http://

akhmadsudrajat.wordpress.com.

Haris. R. (1995). Introduction to Creative Thinking. Dalam http:// virtualslt.com. Diakses 30 Maret 2015

Hasan, Hamid S. (1996). Pendidikan Sosial (buku I \& II). Bandung: FIPS

Hassoubah. Z.I. 2002. Developing Creative \& Critical Thinking Skill (Cara Berpikir Kreatif \& Kritis). Terjemahan Bambang Suryadi. 2004. Bandung: Penerbit Nuansa

Isjoni. 2010. Cooperative Learning. Efektifitas Pembelajaran Kelompok. Bandung: Alfabeta.

Ismaimuza, D. (2010). Kemampuan Berpikir Kritis dan Kreatif Matematis Siswa SMP melalui Pembelajaran Berbasis Masalah dengan Strategi Konflik Kognitif. Disertasi pada PPs UPI. Bandung: Tidak Diterbitkkan

Johnson \& Jonson. 2002. Meaningful Assessment A Manageable and Cooperative Process. Allyn and Bacon: Boston

Kementrian Pendidikan dan Kebudayaan, 2013. dalam http://kemdikbud.go.id/

Khotimah, Khusnul. 2014. Penerapan Pembelajaran IPS Model Discovery Learning untuk 
Meningkatkan Kemampuan Berpikir Siswa MTsN Mojosari.Surabaya. Universitas Negeri Surabaya.

Kemdikbud. 2013. Pendekatan Scientific (Ilmiah) dalam Pembelajaran . Jakarta: Pusbangprodik.

Kemdikbud. 2013. Pengembangan Kurikulum 2013. Paparan Mendikbud dalam Sosialisasi Kurikulum 2013. Jakarta :Kemdikbud

(Kosasih, 1994; Hamid Hasan, 1996). Dalam Direktorat Tenaga Pendidik Dirjen PMPTK Depdiknas. 2008. Strategi Pembelajaran Pendidikan Kewarganegaraan dan Ilmu Pengathuan Sosial. Jakarta.

Martoella,1987.Dalamhttps://akhmadsudr ajat.wordpress.com/2011/03/12/k arakteristik-mata-pelajaran-ilmupengetahuan-sosial-ips/.

Munandar, S.C.U.(2002). Pengembangan Kreativitas Anak Berbakat. Jakarta : PT Rineka Cipta.

Mustaji. 2014. " Application of Problem Based Learning in Higher Education". Dalam The Journal of School Studies Education. Vol 3 Maret.

Nusyamsuddin, dkk. 2013. Pembelajaran Berbasis Kompetensi dengan Pendekatan Saintifik. Jakarta : Kemendikbud RI

Permendikbud No. 65. Pembelajaran IPS Terpadu Dengan Pendekatan Saintifik. 2013
Permendikbud RI nomor 81 A. 2013. Implementasi Kurikulum

Pedoman umum Pembelajaran

Purwanto.2013. Analisis Kemampuan Inkuiry dan Hasil Belajar Siswa Sekolah Menengah Pertama Melalui Model Pembelajaran Berbasis Model Hierarki of Inquiry. Bandung: Universitas Pendidikan Indonesia.

Ralingson J.G. 1997, Berfikir Kreatif dan Brain Storming, Jakarta: Erlangga Matematis

Ruseffendi,E.T. 2005. Dasar-dasar Penelitian Pendidikan dan Bidang Non Eksakta. Bandung: Tarsito.

Sapriya, 2009. Pendidikan IPS.Bandung: PT Remaja Rosda Karya.

Setiawan.2006.Model Pembelajaran Matematika Dengan Pendekatan Investigasi. Makalah (disampaikan dalam penulisan modul paket pembinaan penataran). Yogyakarta: PPPG Matematika.

Surpijono,Agus. 2009. Cooperative Learning Teori dan Aplikasi. Yogyakarta: Pustaka pelajar.

Suyono,Hariyanto.20211. Belajar dan Pembelajaran. PT. Remaja Rosdakarya: Bandung

Syah. Strategi Pembelajaran Discovery Learning. 2004

Trianto.2011. Model-model Pembelajaran Inovatif Berorientasi Konstruktivistik. Prestasi Pustaka: Jakarta

Yamin,Martinis. 2008. Paradigma Pendidik Konstruktivistik. Jakarta: GP Press 
